\title{
AGITAATION OIKEUTUS?
}

JUHA SUORANTA (2005). Radikaali kasvatus. Gaudeamus. $256 \mathrm{~s}$.

$\mathrm{T}$ arina alkaa tavallisesti. Koska kasvatus väistämättä politisoituu, tarvitaan poliittista kasvatusta ja tilanteen juuriin menevää ideologiakritiikkiä. Viimeksi mainittu edesauttaa havaitsemaan vallanalaiset tilanteet ja toimimaan maailman muuttamiseksi yhdenvertaisemmaksi ja paremmaksi.

Väärä tietoisuus näyttäytyy kuitenkin siinä määrin totaalisena yhteiskunnan osana, että voi ihmetellä, miten joku tämän yhteiskuntaluolan asukeista on koskaan onnistunut irtautumaan sen määrittämistä silmälapuista, nähnyt totuuden tai pikemminkin sen peittävän pirullisen salajuonen, ja on nyt valmis vapauttamaan kaikki muutkin sen luomasta harhasta. Vastarinnan pedagogiikka on kumouksellisten välineiden hiomista aikalaisdiagnoosin avulla tavoitteena löytää toivon mahdollisuus. Tällaiselle "diagnoosille" on Suorannan mukaan tyypillistä voimakas näkemyksellisyys, pohtivuus ja runollisuus sekä esteettinen vaikuttavuus, koskettavuus ja jopa liikuttavuus (s. 23), toisessa yhteydessä myös messiaanisuus ja profeetallisuus (s.38). Näiden hyveiden tavoittelusta on myös tässä teoksessa kysymys. Jota- kin pistämättömän pinnallista on kuitenkin jäänyt toteamukseen, että "keskeistä on liittää tieteellinen tieto yhteen käytännöllisen kokemuksen kanssa ja muuttaa näiden yhdistelmä yhteiskunnalliseksi tietoisuudeksi eli praksikseksi” (s. 26). Täysin ideologisoitunut yhteiskunta ei kuitenkaan näyttäisi jättävän tilaa tieteellisen tiedon mahdollisuudelle. Katselenkin tätä Radikaali kasvatus -teosta tästä näkökulmasta.

Historiasta nousee Marx ja Marxista pääoman historia ja yhteiskunnallismateriaalisen määräävyys suhteessa yksilöllis-henkiseen (ml. tiede osana jälkimmäistä). On vaikea nähdä, onko Marxin persoonalliseen vapautumiseen tähtäävä ohjelma pelkkää kapitalismissa välttämätöntä runollista myyntipuhetta vai jotakin tätä painavampaa, mutta monet ovat sen ostaneet takuita peräämättä tai pelkän tuotenimen "aidosti marxilainen, siksi oikeasti edistyksellinen” perusteella. Onko Freiren lukutaidon korostamisen takana se, että köyhät ja sorretut voisivat loppuviimeksi lukea itse totuuden Pääomasta tai oppisivat ymmärtämään sen relevanssin oman tilanteensa käsitteellistämisessä? Suoranta sivuaa myös tätä puolta tarinassa esitellessään Adornon ajattelua. Inhimillisen alennustilan kriittisestä analyysistä (sorto sukupuolen, luokka-aseman jne. perusteella) kumpuaa paremman mahdollisuus kasvatuksen kautta. Radikaalin kasvatuksen teoria ammentaa itseään moninaisista teksteistä. Suoranta lukee radikaalin kasvatuksen maaperään ja juuriin myös fenomenologisia ja eksistentialistisia huomioita ja mainitsee myös Bourdieun ja Foucault'n.

Mutta mitä toisinajattelun mahdollisuus jo itsessään kertoo yhteiskunnasta? Jos väärä tietoisuus läpäisee kaiken, on radikaali ajattelu pelkkä illuusio, joka käytännössä pikemminkin palvelee ja pönkittää vallitsevaa järjestelmää. Näin kapitalismi olisi tarvinnut ja myös luonut oman Marxinsa.

Radikaalin kasvatuksen nykysuuntaukset muodostavat Suorannan mukaan neljä aaltoa. Hän kuvaa kiinnostavasti 1960luvun liikevoiman ehtymistä ja kääntymistä yksilölliseen, luonnehtii lyhyesti uuden kasvatussosiologian syntyä ja pureutuu sitten kulttuuriseen (Giroux) ja kriittiseen suuntaukseen (McLaren). Kahden jälkimmäisen vertailu on varsin onnistunut. Jos opiskelijat vain oppisivat analysoimaan subjektiutensa, unelmiensa ja halujensa ideologista muotoutumista globalisoituneen kapitalismin olosuhteissa, voisivat toivo, välittäminen ja yhteinen tekeminen edistyä koulussa. 
PULMALLINEN JAKO

TEORIAAN JA

KÄYTÄNTÖÖN

Tätä teosta jäsentävä perusjako radikaalin kasvatuksen teoriaan ja käytäntöön näyttää pulmalliselta. Teoriaosassa radikaalin kasvatuksen mahdollisuus itsessään jää vaille selitystä. Ainoastaan sen tarvetta perustellaan "aikalaisdiagnooseilla”, jotka rakennetaan usein Marxin vanhoille huomioille ja perustellaan toteamalla ne edelleen ajankohtaisiksi. Tuloksena on reflektiivisesti heikkoa sosiologiaa, uskonvaraista politiikkaa ja emootioita liikuttavaa kasvatustiedettä.

Radikaalin kasvatuksen käytäntö-osa lähtee liikkeelle kriittisen lukutaidon merkityksestä keskellä perusluonteeltaan konservatiivista, status quota pönkittävää ja siihen sopeuttavaa kulttuuriteollisuutta. Kiinnostava alku hajoaa kuitenkin ennen loppua, kun Suoranta kuvaa "tiedostavien” rock-tähtien hyväntekeväisyystoimintaa kiinnittämättä sen suurempaa huomiota siihen, että "tiedostavuus" vain lisää myyntiä ja on osa kulttuuriteollisuuden markkinointiarsenaalia. Ehkäpä kriittisen pedagogiikan kysyntä itsessään juontuu siitä, että kulttuuriteollisuus on tuotteistanut ja myynyt massoille ko. tiedostamisen tarpeen merkityksen. Täten Radikaali kasvatus -teoskin olisi osa "tiedostamisen" markkinointia massoille osana kulttuuri- ja viihdeteollisuutta.

Kulttuuri on myös käyttökulttuuria ja ihmiset ovat kulttuurin käyttötavoissaan usein innovatiivisia ja kekseliäitä. He sovittavat kulttuurituotteita omaan elämäänsä ja omaa elämäänsä niihin. Toki myös kulttuuriteollisuus on kekseliäs kääntäessään tällaisia omaehtoisesti luotuja kulutus- ja käyttötottumuksia markkinoille tuotetuksi kulttuuriksi.

Suoranta pitää todennäköisenä, että nuorten kokemat ristiriidat koulussa juontuvat osaltaan koulun ja mediakulttuurin suhteesta. Koulu voisi oman asemansa avulla silloittaa nuorten kokemuksia ja auttaa heitä ymmärtämään itseään. Esimerkkinä Suoranta käyttää hiphopia. Hän liikkuu sulavasti populaarikulttuuritutkimuksen virrassa ja näkee hiphop-artistien laajentavan politiikan käsitettä ja avaavan uusia yhteiskunnallisen vaikuttamisen muotoja. Todennäköisesti politiikan käsite ei tässä laajene eikä uutta vaikuttamisen muotoa synny, mutta uusia ryhmiä mahdollisesti tulee näin politiikan piiriin ja täten, kuten Suoranta kirjoittaa, kysymys on uudenlaisen aktiivisen osallistumisen kulttuurin rakentamisesta.

On vaikea tietää, miten vakavissaan Suoranta on todetessaan, että elämän lait opitaan tänään enemmän katujen mainostauluista ja elämyksellisillä "tiedon valtateillä" kuin kodin, koulun tai kirkon piirissä. Onko elämässä tällaisia lakeja? Ja miten tästä seuraa se, että tällöin kasvatuksen yleiseltä määritelmältä edellytetään laajuutta, joka tekee kriittisistä hiphoppareista poliittisia kasvattajia? En tiedä, miksi he kaipaisivat tällaista tutkijoiden taholta tapahtuvaa "virallistamista", sen mukanaan tuomaa sosiaalista hyväksyntää ja valta- ja hallintakulttuuriin sisällyttämistä, varsinkin kun heidän markkina-arvonsa jo antaa heille aseman viihde- ja kulttuuriteollisuudessa.

Osallistava kasvatus, kuten nimikin kertoo, viittaa ihmisten omaehtoisen työn valjastamiseen suurempien päämäärien tavoittelun välineeksi ja työstämisen kohteeksi. Musiikkia koskeva pohdinta johdattaa Suorannan kysymään makukysymyksiä, joissa mahdollisesti olisi ainesta enempäänkin, mutta jotka nyt onnistuvat lopuksi vesittämään muutenkin huonosti jäsentyvän Kulttuuriteollisuudesta yhteiseen kulttuuriin -luvun.

Radikaalit pedagogit kamppailevat luodakseen tietoisen ja kriittisen suhteen tavarakulttuuriin ja brändeihin. Suoranta on toisaalta itse luomassa brändiä “radikaali kasvatus”, jonka koostamisessa hän hyödyntää niin eläviä kuin kuolleitakin ajattelijoita ja kirjoittajia sekä kirjankustannusteollisuutta. Tuloksena on kuitenkin sisällöllisiä huomioita kuluttajien tuottamistekniikoista, vanhempien syyllisyydellä rahastamisesta, koulun virvoitusjuoma-automaateista maailmanlaajuiseen sortoon osallistumisena, koulubrändäyksestä jne. Kriittistä lukutaitoa on esittää kiperiä kysymyksiä yhteiskunnasta, maailmasta, mainonnasta, itsestään selvänä otetusta. Kriittistä lukutaitoa on myös kysyä, missä määrin Marxin kriittisten tulkintojen toistaminen on itsessään kriittistä ja miksi kuvaan ei kuulu pohtia mitä kriittisen ajattelun mahdollisuus itsessään kertoo yhteiskunnastamme.

Yhdenlainen haaste radikaalille kasvatukselle ovat myös spektaakkelit sisällöttömyyden voimana ja kaiken mediapitoisuus. Vastalääkkeeksi nähdään ideologiakriittinen aikalaistietoisuus, so. kapitalismin lukutaito. Katastrofispektaakkelit, auttamisviihde, muista maista tuleva 
hallusinogeeninen kurjuus läntisen kulttuurin itsetuhoisena käyttövoimana, sensuuri ja propaganda, Hollywood-pedagogiikka on ymmärrettävä oikein.

Kumouksellisuus näyttää kaipaavan aina jonkin konkreettisen kohteen, oman Bastiljinsa, jota vastaan hyökätä. Suoranta ei kuitenkaan usko tällaiseen moderniin monologismiin radikaalin kasvatuksen perustana, mutta hän haluaa kuitenkin nimetä globalisoituneen kapitalismin ja alistavat hallintakoneistot maalitauluiksi. Ongelmana on kuitenkin vallitsevan järjestelmän totaalisuus ja kasvottomuus. Tästä syystä radikaalit kasvattajat tulevat todennäköisemmin Marsista kuin Maasta.

Radikaalin kasvatuksen käytäntö-osan viimeinen luku käsittelee radikaalin kasvatuksen yleisiä periaatteita ja radikaalin kasvattajan ominaisuuksia. Kasvatuksen tulisi vapauttaa sisäisesti, ulkoisesti ja yhteistoimimaan muiden vapauttamiseksi osana oikeudenmukaisempaa, yhdenvertaisempaa ja yhtenäistä maailmaa. Radikaali oppiminen versoo verkostoissa, jotka ylittävät yhteiskunnallisia rajanvetoja ja synnyttävät uutta dialogia, ymmärrystä ja uusia toimijakombinaatioita. Radikaalin kasvattajan tulee Suorannan mukaan ymmärtää oma paikkansa maailmassa ja tuntea itsensä. Hänen katseensa on suora, hän pitää kiinni toivosta, tunnistaa epäkohdat, osaa ajatella, on määrätietoinen, myötätuntoinen, luova, itsenäinen, riippumaton auktoriteeteista ja toimivan itsereflektion omaava. Hän on jossakin määrin muukalainen, oman tiensä kulkija ja tarkkailija, joka on vapaa objektiivista havainnointia tai arviointia sitovista kiinnityksistä ja uskomuksista.

Eipä siis ihme, että radikaaleja kasvattajia on harvassa, jos ollenkaan. Hän on mitä ilmeisimmin onnistunut jotenkin ylittämään yhteiskunnallisen itsensä, irtautumaan platonisen luolan kahleista ja erottamaan harhojen ja heijastumien kätkemän todellisuuden. Hän lienee itse myös radikalisoinut itsensä. Nyt hän palaa kertomaan meille kahlehdituille visionsa siitä, mistä kurjuutemme oikein juontuu ja millainen todellisuus todella on. Hän on lisäksi oivaltanut, että on parempi antaa meidän itse keksiä se oikea vastaus johdattamalla meitä sokraattiseen tapaan (näennäisen) dialogin avul- la. Kun päädymme sanomaan syyksi kapitalismin, saamme kuulla olevamme oikeassa ja tiedostavamme viimein olennaisen.

Kokonaisuutena tämä teos ei millään tavalla jakaudu radikaalin kasvatuksen teoriaan ja käytäntöön, vaikka se näyttäisikin tekevän niin. Se on sujuvasti kirjoitettu, intomielinen, tunteisiin vetoava, taitavasti kaunokirjallisuutta hyödyntävä ja tarpeellinen muistutus kasvatuksen haasteista tämän päivän maailmassa. Luettavuus tekee siitä kiinnostavan oppikirjan, jonka käytettävyyttä kuitenkin heikentää käsittelyn pirstaleisuus ja pinnan moninaisuudessa juhliminen asian juuriin menemisen sijaan. Suorannan teos on nähdäkseni tuorein osoitus siitä, että kasvatus on perusluonteeltaan aina konformistista. Radikaali kasvatus kääntyy tällöin aina radikaalin kasvattamiseksi jonkin radikaaliuden määritelmän alla. Näin todellista radikaaliutta joudutaan aina hakemaan jostakin kasvatuksen tuolta puolen.

\section{Vesa Huotari}

